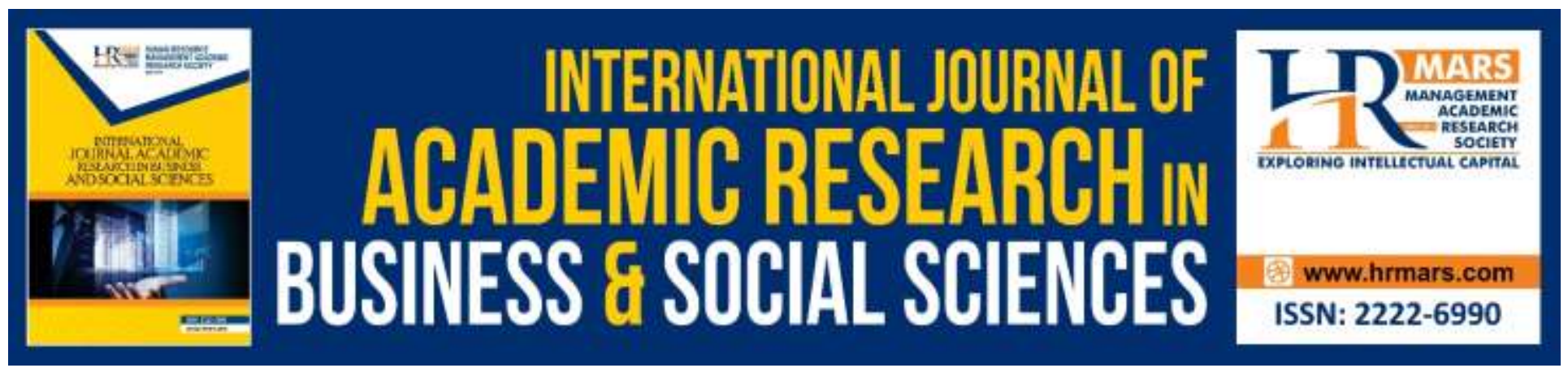

\title{
The Importance of Generic Skills for Technical and Vocational Students Employability
}

Haron, M. A., Mohammad Hussain, M. A., Ali, E., Che Rus, R., Mohammad Zulkifli, R.

To Link this Article: http://dx.doi.org/10.6007/IJARBSS/v9-i7/6089

DOI: $10.6007 /$ IJARBSS/v9-i7/6089

Received: 01 May 2019, Revised: 27 May 2019, Accepted: 13 June 2019

Published Online: 23 July 2019

In-Text Citation: (Haron, Mohammad Hussain, Ali, Che Rus, \& Mohammad Zulkifli, 2019)

To Cite this Article: Haron, M. A., Mohammad Hussain, M. A., Ali, E., Che Rus, R., \& Mohammad Zulkifli, R. (2019). The Importance of Generic Skills for Technical and Vocational Students Employability. International Journal of Academic Research in Business and Social Sciences, 9(7), 33-45.

Copyright: (C) 2019 The Author(s)

Published by Human Resource Management Academic Research Society (www.hrmars.com)

This article is published under the Creative Commons Attribution (CC BY 4.0) license. Anyone may reproduce, distribute, translate and create derivative works of this article (for both commercial and non-commercial purposes), subject to full attribution to the original publication and authors. The full terms of this license may be seen

at: http://creativecommons.org/licences/by/4.0/legalcode

Vol. 9, No. 7, 2019, Pg. 33 - 45

http://hrmars.com/index.php/pages/detail/IJARBSS

JOURNAL HOMEPAGE

Full Terms \& Conditions of access and use can be found at http://hrmars.com/index.php/pages/detail/publication-ethics 


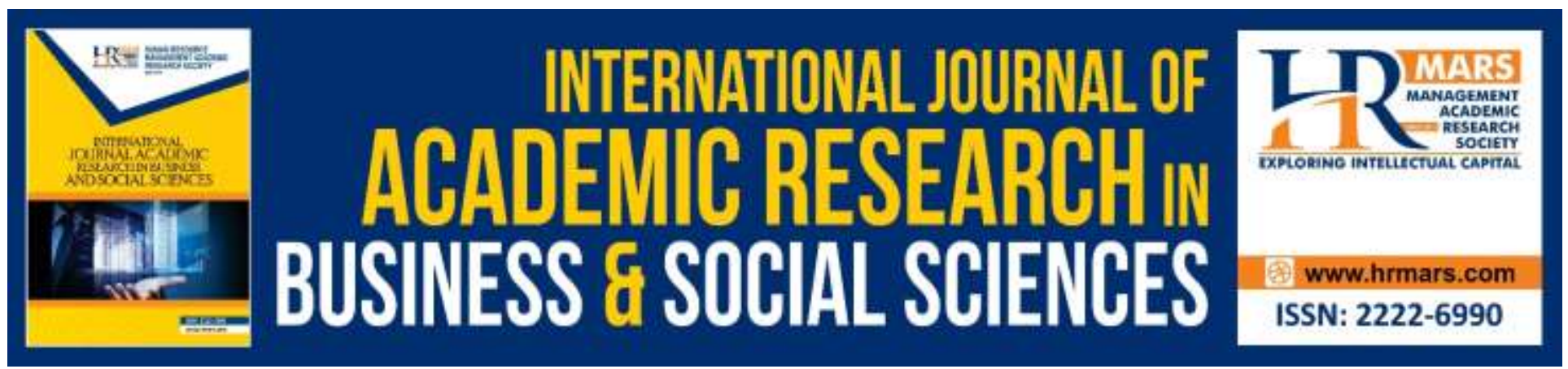

\title{
The Importance of Generic Skills for Technical and Vocational Students Employability
}

\author{
Haron, M. A., Mohammad Hussain, M. A., Ali, E., Che Rus, R., \\ Mohammad Zulkifli, R.
}

Fakulti Pendidikan Teknikal dan Vokasional, Universiti Pendidikan Sultan Idris

Tanjung Malim, 35900, Perak

Email: azlan_hussain@ftv.upsi.edu.my

\begin{abstract}
Technical and vocational education is no longer a "second class" option in the eye of the community because of its significant role in producing human capital for industries. Hence, consistent efforts have been done by Technical and Vocational Education and Training (TVET) institutions to enhance the students' skills and capability. Recently, a lot of graduates are unable to secure a job after graduating because of a failure to meet the employer's expectation. The reasons are because employers normally have their preference criteria in recruitment, such as having a good employability skills. Therefore, this concept paper has been developed in order to study the importance of generic skills in improving the employability of Malaysian vocational students. The "CareerEDGE" model have been used to further discuss the relevant generic skills needed by TVET students in Malaysia. In addition, the elements of generic skills that are important to vocational students will be identified then it will be presented to the stakeholder, which are The Malaysia Ministry of Education in formulating effective vocational education and training strategies towards the development of high skilled and competitive graduates. In this study, critical thinking and problem-solving skills, communication skills and leadership skills have been discovered as the main components of generic skills to be addressed to vocational school students. As a conclusion, generic skills should be applied thoroughly by all parties because it will benefit the student by improving their skills and self-esteem in order to compete in the career world.
\end{abstract}

Keywords: Generic skills, Employability, Technical and Vocational Education

\section{Introduction}

The main objective of an academic program in educational institutions is to produce learners who are both knowledgeable and skilled which is in line with the demand and requirement from the industry. Hence, the bilateral relations between educational institutions and the industry, especially the private sector should be intensified in order to produce graduates that are highly skilled as well as ready to face the world of work through the implementation of industrial training programs. This 
INTERNATIONAL JOURNAL OF ACADEMIC RESEARCH IN BUSINESS AND SOCIAL SCIENCES Vol. 9, No. 7, July, 2019, E-ISSN: 2222-6990 @ 2019 HRMARS

study systematically reviews on literature in order to identify generic skills among Technical and Vocational Education and Training (TVET) that perceived importance by their pottention employer from industries. The outcome of this study will be used to contribute on the effort of developing effective human capital that ready to enter the job market. According to Sağlam dan Oral (2010), effective human capital is a important elements in national development is to be able to provide. Hence, as a developing country, Malaysia has responsibilities to produce sufficient human capital that comes with qualities in the effort to produce skilled, flexible and knowledgeable workers (Biden \& Kamin, 2013). The human capital in mentioned is the formation of man as the main asset for the success of a country's development process. Hence, development of cognitive, affective and psychomotor elements should be applied to educate young people as an effort to advance the country (Majid \& Rahim, 2009). In order to develop a qulity human capital with sufficient cognitive, affective and psychomotor elements, TVET program hold a big responsibility. As an example, in the aspect of psychomotor, Technical and Vocational Education have been very useful in developing students with technical and kinesthetic abilities. In regard of cognitive aspects, problem-based learning has been introduced to the student through TVET teaching and learning activities, while studnets' affective aspects, aslo been trained to be more self-reliant and to cooperate with each other when carried out the task through the soft skills module which had been applied in TVET.

One of the effort that has been done by Malaysia to achieve the nation's aspiration to produce first-class human capital is the transformation of technical and vocational education through the Eleventh Malaysia Plan, 2016-2020 (RMK-11). In short, first-class human capital can be understood as the characteristics of human capital that meet the needs of an individual, family, and society development. The characteristics of these first-class human capital emphasize on the development of knowledge, skills, intellectual, entrepreneurship ability as well as high moral ethic values (Mohamad \& Salleh, 2009). In the Eleventh Malaysia Plan, the agendas of producing human capital that are high-profile, knowledgeable, and have a positive attitude are one of the important elements to enhance the country's global economy. Based on this plan, TVET transformation is important to be implemented as the national economic agenda had predicted a total of 1.5 million employment opportunities will be available by the year of 2020 with the target to reduce dependency on moderate-skilled foreign workers. In addition, $60 \%$ of skilled workers will be developed in the final phase of preparing Malaysia to become a developed nation by emphasizing world-class human capital (Economic Planning Unit, 2015).

Curently, only $25 \%$ of Malaysian workforce are highly skilled while $80 \%$ of the workers only hold a Malaysia Certificate of Education which is a high school certificate. The government had aimed to increase the numbers of skilled workers by $35 \%$ by 2020 under the Eleventh Malaysia Plan (Economic Planning Unit, 2015). To cater the target, TVET are continuously strengthened by the government. As example the government had allocated RM270 million to upgrade learning equipment at TVET institutions and another RM360 million were allocated to the Skills Development Fund Corporation to lend money for TVET students who wish to enter TVET programs in public and private institutions (Ministry of Finance Malaysia, 2017). Besides, various programs had been developed such as the National Dual Training System (NDTS) in which had been adapted from the TVET training model (Department of Skills Development Malaysia, 2016). The NDTS, which is an apprenticeship-oriented training is expected to boost employment opportunities for the graduates as the government intends 
INTERNATIONAL JOURNAL OF ACADEMIC RESEARCH IN BUSINESS AND SOCIAL SCIENCES Vol. 9, No. 7, July, 2019, E-ISSN: 2222-6990 @ 2019 HRMARS

to produce high-skilled workers. Through the NDTS program, the learning process is carried out in two situations in which $80 \%$ of it is learning being conducted in the workplace (company) and another $20 \%$ the learning process happened in educational institutions. The NDTS concept provide graduates the value-added skills as well as enhancing individual specific abilities through knowledge, information, practice, and attitudes (Rhouse \& Razak, 2006).

\section{Generic Skills}

Several generial terms have been used worldwide to explain the meaning of generic skills. The generic skills term used by each country can be seen in details as shown in Table 1 below.

Table 1 The generic skills term according to a country.

\begin{tabular}{ll}
\hline Country & The Generic Skills Term \\
\hline Singapore & Critical enabling skills \\
United Kingdom & Core skills, key skills, general skills, and transferable skills \\
New Zealand & Essential skills \\
Australia & Key competencies, employability skills, and generic skills \\
Canada & Employability skills \\
United State & Basic skills and workplace skills \\
France & Transferable skills \\
Switzerland & Transdisciplinary goals \\
Malaysia & Generic skills and soft skills. \\
& \\
\hline
\end{tabular}

Researchers around the world have proposed various definitions of generic skills. In accordance with Ariffin and Ishak (2009), generic skills are non-technical skills needed by students aside from academic achievement in order to ensure they are outstanding and successful in various aspects including job placement. Buntat (2000) had defined generic skills as non-technical skill that is very important for personality development also in preparing students to be a competitive. According to Husain, Mokhtar and Alias (2015), generic skils are non-technical skills, which are very important for graduates employability. Studies show that employees will gain success and job satisfaction if they can master these generic skills compared to only have the technical skills. The Ministry of Higher Education (2006) defines generic skills as a skill that comprises cognitive elements in which related to non-academic skills such as teamwork, communication skills, leadership, moral values, and continuous learning. A generic skills also a multiskills that must exists or present in each students where it can act as their key indicator after graduation and when looking for job opportunities. Therefore, academic achievement alone is no longer the only key factor and that educational institutions should provide training and guidance for the students to develop their abilities, talents, and potentials in order to compete in the job market after their graduation. From the previous written report and research that can be found clearly that generic skills are needed by every graduate 
INTERNATIONAL JOURNAL OF ACADEMIC RESEARCH IN BUSINESS AND SOCIAL SCIENCES Vol. 9, No. 7, July, 2019, E-ISSN: 2222-6990 @ 2019 HRMARS

to improve the quality of work. Graduates who managed to master high generic skills will have higher opportunities to get a job in the industry and able to withstand their career (Husain et al., 2013).

\section{The Generic Skills of Tvet Students' Employability}

Figure 2 below shows the model of TVE students' employability that has been modified from the CareerEDGE model. Based on the presented figure below, generic skills are seen as one of the key elements that will qualify TVE students to apply for a job. This model also shows that in addition to generic skills, there are several other elements that show a link of direct interaction, which is selfeffeciency, self-confidence and self-appreciation in order to achieve the main objective of an employment. Besides that, in order to reach the goal, there is another factor that need to be taken into consideration, which is the element of self-reflection.

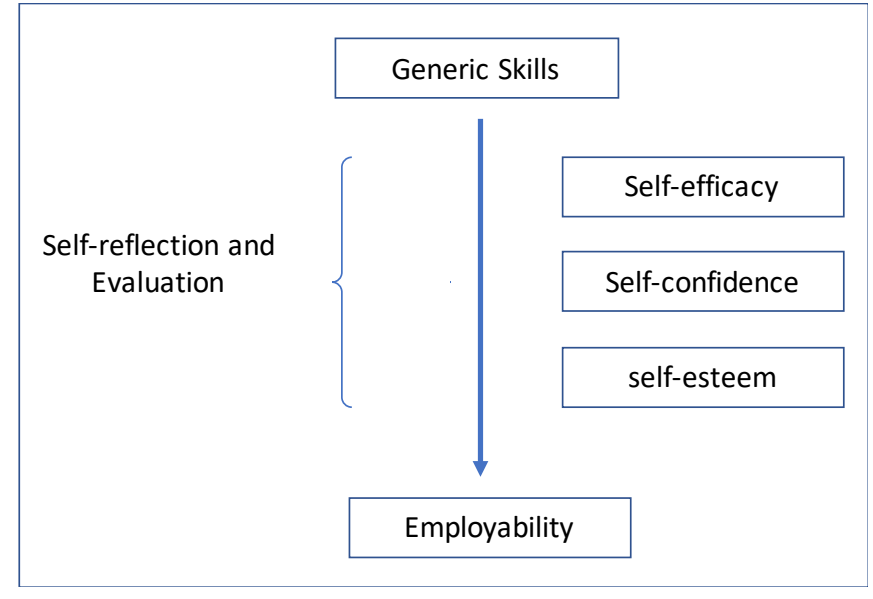

Figure 2 The model of TVET students' employability that had been modified from the Career EDGE model by Pool and Sewell. (2007)

The student's employability model was created to show improvement in the process of generating career employment for graduates studying TVET in Malaysia. This model was also expected to be used as a guidance to the relevant parties in developing a program towards graduates' employabilities. The ministry and stakeholders need to consider what are the most appropriate methods to improve the capabilities of the TVET centres in the context of developing generic skills such as providing professional training for lecturers and teachers so that they can help to improve the readiness of students to enter the job market. In addition, the industry, especially employers should be able to see the role of TVET schools and institutions in producing workers that fulfill the needs of industry.

\section{Self-reflection and Evaluation}

Generally, reflection can be considered as reviewing, recollecting or recalling the experiences and activities that have been carried out, while he evaluation refers to a consideration or making decisions regarding some matters (Mustafa, Yussof, Aziz, Sobri \& Ismail, 2012). In regard of TVET students, the process of teaching and learning either inside or outside of the classroom should 
provide students with opportunity to reflect and evaluate knowledge skills that have been acquired after the learning process. By doing self-reflection and evaluation, students can perform a selfreflective process as an effort to develop their self-esteem. Reflection and evaluation are one of the key elements among TVET graduates' in qualifying for employment. Consequentially, students will start to consider and analyze whether they have the capabilities, talents, confidence, beliefs, or able to be independent and manage theirself when being given tasks in their future job. In short, reflection and assessment have a significant relationship aside from other elements such as self-esteem, selfconfidence, and self-esteem in improving the employability of TVET students.

\section{Self-Efficacy}

Self-efficacy refers to the belief and ability of person to organize and conduct the action to accomplish a task that are given to them (Bandura, 1995). Self-efficacy also affects one's actions and abilities to think and act. Bandura (1995) also stated that there are three sources of self-efficacy: -

i. Mastery experiences

ii. Indirect experience through social models

iii. Social influence

\section{i) Mastery experiences}

According to Pool \& Sewell (2007), mastery experiences occur when students are given the opportunity to undergo job training through a realistic work environment. This method is also very effective to establish self-confidence in developing workers that are desired by employer. For example, in order to produce high-skilled vocational graduates and fulfill the industry demands, On the Job Training (OJT) program has been implemented by Technical and Vocational Education Division under the Ministry of Education in all Vocational Colleges in Malaysia. The main objective of OJT's implementation is to expose graduates to the real-time employment to become familiar with industrial setting and to provide them with better chances for employment.

\section{ii) Indirect experiences through social models}

Individual self-efficacy levels can be enhanced via an indirect method of experience through social models. An individual will strive to succeed when he or she sees others who are similar to themselves had already succeeded. As an analogy, through university alumni program where former students are called to share their success with the student who are still studying at the same university. This program of sharing experiences and how they strive for success will make students more motivated to increase their level of self-efficacy (Abdullah, Muhamad, Talip, Ambotang, \& Zain, 2012).

\section{iii) Social influences}

Social influences happened when an individual is convinced by another person to perform an activity using existing abilities. This situation had indirectly encouraged the individual to strive and feels motivated in order to achieve all the goal and the desired outcome. In this case, counselors and instructors such as lecturers and teachers play an important role in executing the method of social influence. During the process of teaching and learning in the lecture hall, lecturers also play 
an important role in providing motivation and guidance to the students in order to shape their tendencies and interests towards the suitable field of work. If the lecturer is mastered in the field of civil engineering, the lecturer will definitely put emphasized to careers in the engineering field in which it can be closely related to the construction field such as architects, engineers, assistant engineers, site supervisors, and many more to develop the student interests towards the following job opportunity. Information provided by lecturers were linked to changes that happened in the social and psychological behavior of students. This process is called psychosocial or internal values where it works to improve self-confidence, self-adjustment, and career, responsible in performing tasks, and have an interpersonal ability (Ismail et al., 2007).

Therefore, individual self-efficacy can be enhanced through the implementation of these three elements. Graduates who have high confidence in their abilities and talents are more likely to find jobs than passive graduates who do not have any confidence in their abilities (Pool \& Sewell, 2007).

\section{Self-Confidence}

Self-confidence is the ability of an individual to trust and believe above his ability to do something. Hassan (2002) had proposed that among the reason that graduates fail in job interview was because they failed to convince the employers regarding their own advantages and abilities. This proves that self-confidence is very important for graduates in the pursuit of employment. In addition, communication skill is another generic skill element that is widely associated with self-confidence. Research conducted by Mohd Makhbul et al. (2015) indicates that employers are very particular regarding graduates' self-confidence when determining whether they will be among the top priorities in filling the company vacancies. Hence, strong self-esteem, followed by an effective communication skills is among the advantages that will ensure the graduate becomes the employer's choice.

\section{Self-Esteem}

Self-esteem is an individual self-assessment of himself. This assessment also considers views from other people and how the individual assesses certain experiences in his or her life. Self-esteem in the aspect of generic skills is the individual ability to manage independently their chosen career when facing career opportunities (Fugate, Kinicki, \& Ashforth, 2004). In accordance to Che Noh (2004), individuals with high self-esteem will feels that they are respected, have a bright chance in the field that they are involved in, and always be positive when doing tasks while a low self-esteem individual will feels that they are worthless, always feels threatened, and full of uncertainties towards oneself. Therefore, high self-esteem is essential for students when seeking career opportunities. In addition, the key to get success in job placement is to increase the self-esteem. This is because a graduate should trust his ability to succeed and improved his self-development as well as to develop good potential in both career and life.

\section{Study on Generic Skills towards Tve Field in Malaysia}

Various studies on the importance of generic skills have been conducted in Malaysia. Table 2 shows the most important generic skills based on reviewed conducted on 11 studies related to TVET students' generic skills. These studies have been conducted in various Malaysian TVET institutions 
including Elementary Vocational Education (PAV) program, Technical schools, Vocational colleges, Community colleges, Polytechnics, MARA Skills Institute, and Malaysia university that offered the technical program. Based on the Table 2. communication skill, leadership skill, as well as chritical thinking and problem solving has been found as the most popular generic skills, which have been mentioned as important for TVET student in six out of 11 studies, followed by teamwork (five out of 12 studies). 
Table 2: The element of generic skills that are important based on the opinion of researchers.

\begin{tabular}{|c|c|c|c|c|c|c|c|c|c|c|}
\hline \multirow[b]{2}{*}{ References } & \multicolumn{9}{|c|}{ Important elements of generic skills } & \multirow[b]{2}{*}{ K } \\
\hline & A B & $\mathbf{C}$ & D & $\mathbf{E}$ & $\mathbf{F}$ & G & $\mathbf{H}$ & $\mathbf{I}$ & J & \\
\hline Husain et al., (2013) & $\boldsymbol{V} \mathbf{v}$ & $\mathbf{v}$ & $\sqrt{ }$ & & & & & & & \\
\hline $\begin{array}{l}\text { Mustapha, Husain, Syed } \\
\text { Mohamad, \& Mokhtar, } \\
(2014)\end{array}$ & & & $\sqrt{ }$ & $\mathbf{v}$ & $\sqrt{ }$ & $\mathbf{v}$ & & & & $\mathbf{v}$ \\
\hline $\begin{array}{l}\text { Rasul, Ismail, Ismail, } \\
\text { Rajuddin, \& Rauf, (2009) }\end{array}$ & & & & & & & $\mathbf{v}$ & $\mathbf{v}$ & $\mathbf{v}$ & \\
\hline $\begin{array}{l}\text { Haslina Md Yunus, Abdul } \\
\text { Razaq Ahmad, \& Anisa } \\
\text { saleha, (2015) }\end{array}$ & & & $\boldsymbol{v}$ & $\boldsymbol{V}$ & $\mathbf{v}$ & & $\mathbf{v}$ & & $\boldsymbol{v}$ & \\
\hline $\begin{array}{l}\text { Husain, Mokhtar, \& Alias, } \\
\text { (2015) }\end{array}$ & & & & $\mathbf{v}$ & $\mathbf{v}$ & $\boldsymbol{v}$ & & & & $\mathbf{v}$ \\
\hline $\begin{array}{l}\text { Amiruddin, } \begin{array}{l}\text { Ngadiran, } \\
\text { Zainudin, \& Ngadiman, } \\
(2016)\end{array}\end{array}$ & $\mathbf{v}$ & $\mathbf{v}$ & & $\mathbf{v}$ & $\mathbf{v}$ & $\mathbf{v}$ & & & & \\
\hline Hanapi et al., (2016) & $\boldsymbol{v}$ & $\mathbf{v}$ & & & $\mathbf{v}$ & & & $\mathbf{v}$ & & \\
\hline $\begin{array}{l}\text { Buntat, Saud, \& Hussain, } \\
\text { (2008) }\end{array}$ & $\boldsymbol{v}$ & & & & $\sqrt{ }$ & $\mathbf{v}$ & & & & \\
\hline Hanafi, (2015) & & & & $\mathbf{v}$ & & V & & & & \\
\hline $\begin{array}{l}\text { Mohd Yusop, Ahmad, } \\
\text { Yogeshwari, \& Zurina, } \\
\text { (2008) }\end{array}$ & $\boldsymbol{v}$ & & & $\mathbf{v}$ & & $\mathbf{v}$ & & & & \\
\hline Number of study & 15 & 3 & 3 & 6 & 6 & 6 & 2 & 2 & 2 & 2 \\
\hline
\end{tabular}




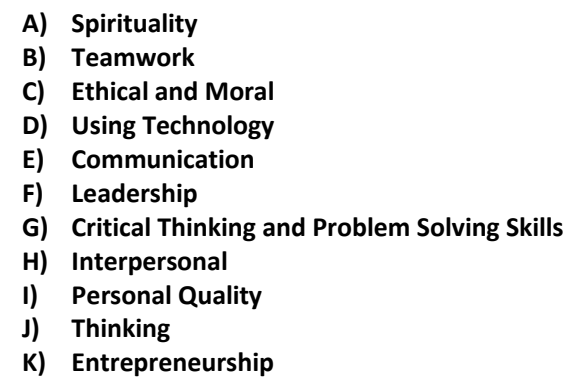

\section{The Importance of Generic Skills}

In accordance with Schultz (1972), human capital is the most important factor in production compared to physical capital and financial. His findings show that the increasing of workforce quality and income has a close relationship with the improvement of educational attainment. Through the empirical study conducted by Schultz (1972) on the trend of US economic growth in the agricultural sector, he found that generic skills, technical skills, and education were actually a complementary to each other. Hence, generic skills also play an important role in the development of human capital in order to produce highly skilled workers.

To produce human capital that is both excellent and knowledgeable, the TVET graduated who are looking for employment have to be equiped with essential generic skills which are important to increase productivity and competitiveness (Amiruddin, Samad, \& Othman, 2015). Currently, employers in the industry stated that most graduates are not able to acquire the career that they want because they have lack of generic skills such as positive work ethics, communication skills, teamwork, decision-making capabilities, and leadership (Hanapi et al., 2016). Thus, generic skills are very important in which graduates need to master those skill in order to help them improve their chances of employment.

A sudden change in various aspects such as social, economy, education demand student to equip themselves with a variety of basic skills that will qualify them for employment opportunities in industry. There is a study have found that emploter actualy belief that generic skills actually more important than technical skills. A study conducted by Cotton (2003) as example, shows that employers are disappointed that generic skills are not truly mastered by graduates whose seeking employment. The findings are then supported by the study conducted by Mohamed, Isa, \& Shafii (2007) which found that generic skills are the most important skill among many other skills that are needed by graduates for their employment.

In the employer's view, the combination of some generic skills criteria is much more important compared to a certain degree certificate when applying for a job. Abdullah (2007) stated in his study that current employers are not only preferred employees with the technical skills, but the employee also required to equip themselves with generic skills so that they can carry out the task given in order to enhance the productivity of the company as well as be competitive. The findings of this study are similar to that of Pineteh (2012) which stated that employers in the job sector prioritized thaier employee candidates based on their generic skills attainment. 


\section{Final Thought and Implication for Practices}

Systematically reviews on literature have found that ccademic knowledge alone is no longer a major factor in determining the TVET student employment but as for now, generic skills are considered as the most important asset by employers in choosing candidates to fill in the vacancy in their company (Mohd Makhbul et al., 2015). Most researchers agreed that generic skills are very important and needs to be applied to TVET graduates, especially in providing added value for them to compete for the employment in the competitive job market after graduation. This study also found that there were three important generic skills elements need to be mastered by TVET students in order to have a better chances or employment which are self-efficacy, self-confident and self-esteem. Inorder to develop these generic skills on TVET students, educators such as lecturers and teachers are the main agents responsible to produce TVET graduates who can utilize their knowledge and skills to fulfill the needs of the country. TVET educators with extensive teaching experiences are needed to develop students with generic skills during the teaching and learning process. Beside that, quality of the curriculum used by the educators have to be improved to help develop the student generic skills as well as to achieve the Malaysian aspirations to become a developed country by 2025.

\section{Acknowledgments}

This research study was supported by the 2017 Universiti Pendidikan Sultan Idris Research Grant. The title of this study is The Need for Professional Development Among Interim Teachers in Vocational Colleges (2017-0117-106-01).

\section{References}

Abdullah, M. Y., Muhamad, B., Talip, R., Ambotang, A. S., \& Zain, S. (2012). Motivasi Dari Perspektif Pendidikan. Utusan Borneo, p. B4.

Abdullah, N. H. (2007). Pengurusan Kemahiran Insaniah dalam Membangunkan Modal Insan Melalui Aktiviti Ko-Kurikulum di UTHM. (Doctoral dissertation, Tesis Sarjana Tidak Diterbitkan. Batu Pahat, Johor: UTHM [Universiti Tun Hussein Onn Malaysia]).

Amiruddin, M. H., Ngadiran, I. A., Zainudin, F. L., \& Ngadiman, N. (2016). Tahap kemahiran generik pelajar Malaysia dalam proses pengajaran dan pembelajaran : Kajian kes pelajar Institut Kemahiran Mara, Johor Baharu Malaysian students' I evel of generic skill in teaching and learning process : A case study of Mara Skills Insti. Journal of Society and Space, 3(3), 111-121.

Amiruddin, M. H., Samad, N. A., \& Othman, N. (2015). An Investigation Effects of Mastery Learning Strategy on Entrepreneurship Knowledge Acquisition among Aboriginal Students. Procedia Social and Behavioral Sciences, 204(November 2014), 183-190.

https://doi.org/10.1016/j.sbspro.2015.08.131

Ariff, T. M. T. (2002). Ciri-ciri Kualiti Pelajar Untuk Keperluan Pekerjaan Pada Masa Kini, Seminar Antara Industri dan Institusi Pendidikan Awam.

Bandura, A. (1995). Exercise of personal and collective efficacy in changing. New York: Cambridge University Press.

Buntat, Y. (2000). Kemahiran “Employability" ( Soft Skills ) dan Kepentingan Penerapannya di Kolejkolej Kediaman Pelajar. Program, (March).

Buntat, Y., Saud, M. S., \& Hussain, H. A. (2008). Cabaran Politeknik Sultan Ahmad Shah (POLISAS) 
INTERNATIONAL JOURNAL OF ACADEMIC RESEARCH IN BUSINESS AND SOCIAL SCIENCES Vol. 9, No. 7, July, 2019, E-ISSN: 2222-6990 @ 2019 HRMARS

Membangunkan Modal Insan Sejajar Dengan Keperluan Sektor Industri. International Conference on Education, 1-12.

Che Hasniza Che Noh. (2004). Hubungan keluarga dari aspek komunikasi dan gaya keibubapaan. Communication, 45-57.

Cotton, K. (2003). Developing employability skills. Northwest Regional Educational Laboratory.

Fugate, M., Kinicki, A. J., \& Ashforth, B. E. (2004). Employability: A psycho-social construct, its dimensions, and applications. Journal of Vocational Behavior, 65(1), 14-38. https://doi.org/10.1016/j.jvb.2003.10.005

Hanafi, S. B. (2015). Kesediaan Pelajar dari Aspek Kemahiran Teknikal Terhadap Pembentukan Kebolehkerjaan di Kolej Vokasional Wilayah Selatan. Universiti Tun Hussein Onn.

Hanapi, Z., Kamis, A., Kiong, T. T., \& Hanapi, M. H. (2016). Jurang integrasi kemahiran employabiliti di Malaysia : Satu kajian empirikal graduan kejuruteraan Kolej Komuniti Integrated employability skills gaps in Malaysia : An empirical study of Community College graduates, 3(3), 145-153.

Haron, M. A., Mohammad Hussain, M. A., Ali, E., Che Rus, R., \& Mohammad Zulkifli, R. (2019). The Importance of Generic Skills for Technical and Vocational Students Employability. International Journal of Academic Research in Business and Social Sciences, 9(7), 1-14.

Haslina Md Yunus, Abdul Razaq Ahmad, \& Anisa saleha. (2015). Kemahiran Insaniah ke arah Pembentukan Potensi Pelajar. 7th International Seminar on Regional Education, 1, 198-215.

Husain, M. Y., Mokhtar, S. B., \& Alias, A. H. (2015). Persepsi Pelajar Kejuruteraan Politeknik Terhadap Kemahiran Employability : Satu Kajian Kes ( Polytechnic Engineering Students Perceptions of the Employability Skills : A Case Study ). Advanced Journal of Technical and Vocational Education, 1(2), 25-32.

Husain, M. Y., Rasul, M. S., Mustapha, R., Malik, S. A., Amnah, R., \& Rauf, A. (2013). Jurnal Teknologi Full paper Tahap Kemahiran Employability Pelajar Kejuruteraan dari Perspektif, 1, 31-39.

Ismail, A., Abu Bakar, R., Nailul Munna Abg Abdullah, D., Maja, A., Ong Guatleng Muhammad Madi Abdullah Politeknik Kuching, C., Kunci, K., ... dan Prestasi Pengajian, P. (2007). Peranan Program Mentoring Dalam Pembangunan Pelajar: Satu Kajian Di Sebuah Universiti Awam Di Malaysia Timur. Malderez \& Bodoczky, Dondero(Ogos), 18-19.

Jabatan Pembangunan Kemahiran Malaysia. (n.d.).

Kementerian Kewangan Malaysia. (2017). Ucapan Bajet Tahun 2017. In Mof (pp. 1-64). https://doi.org/10.1017/CB09781107415324.004

Majid, M. K. A., \& Rahim, R. A. A. (2009). Perubahan Sosial Dan Impaknya Terhadap Pembentukan Modal Insan Menurut Ibn Khaldun. Journal Of Hadhari, 1, 45-76.

Mohamad, B., \& Salleh, M. J. (2009). Pembangunan Modal Insan Sebagai Satu Pelaburan Penting Dalam Konteks Pembinaan Negara, 23-24.

Mohamed, A., Isa, F. L. M., \& Shafii, H. (2007). Kemahiran di kalangan graduan sebagai kriteria penting pasaran tenaga kerja: kajian kes graduan fakulti kejuruteraan, UKM. Seminar Pendidikan Kejuruteraan Dan Alam Bina.

Mohd Makhbul, Z., Yussof, I., Hair Awang, A., Ekonomi dan Pengurusan, F., Kebangsaan Malaysia, U., \& Sains Sosial dan Kemanusiaan, F. (2015). Antara realiti dan harapan - Kajian empirikal persepsi majikan terhadap prestasi graduan tempatan. Fakulti Ekonomi Dan Pengurusan, 
INTERNATIONAL JOURNAL OF ACADEMIC RESEARCH IN BUSINESS AND SOCIAL SCIENCES Vol. 9, No. 7, July, 2019, E-ISSN: 2222-6990 @ 2019 HRMARS

Universiti Kebangsaan Malaysia, Bangi, Selangor, 2Fakulti Sains Sosial Dan Kemanusiaan, Universiti Kebangsaan Malaysia, Bangi, Selangor, 10(10), 27-36.

Mohd Yusop, A. H., Ahmad, E., Yogeshwari, V., \& Zurina, Y. (2008). Sumbangan Kurikulum dan Kokurikulum Bagi Penguasaan Kemahiran Generik Terhadap Pelajar Tahun Akhir UTHM. Persidangan Pembangunan Pelajar Peringkat Kebangsaan 2008, 22-23.

Mustapha, R., Husain, M. Y., Syed Mohamad, S. A. M., \& Mokhtar, seri bunian. (2014). Persepsi Majikan Kejuruteraan Terhadap Tahap Kemahiran Empolyabiliti Pelajar Kejuruteraan Institusi Teknikal: Satu Kajian Kes. Journal Of Science, Mathematics and Technology, 1(2), 41-55. https://doi.org/10.13140/2.1.5118.9120

Nurazimah Biden, \& Yusri Kamin. (2013). Implikasi Penjenamaan Semula Sekolah Menengah Vokasional (SMV) Kepada Kolej Vokasional (KV). 2nd International Seminar on Quality and Affordable Education (ISQAE 2013), (Isqae), 316-323.

Pineteh, E. A. (2012). Using virtual interactions to enhance the teaching of communication skills to information technology students. British Journal of Educational Technology, 43(1), 85-96. https://doi.org/10.1111/j.1467-8535.2011.01193.x

Pool, L. D., \& Sewell, P. (2007). The key to employability : developing a practical model of graduate employability, 49(4), 277-289. https://doi.org/10.1108/00400910710754435

Rasul, M. S., Ismail, M. Y., Ismail, N., Rajuddin, R., \& Rauf, R. A. (2009). Aspek Kemahiran ‘ Employability' yang Dikehendaki Majikan Industri Pembuatan Masa Kini ( Aspects of Employability Skills Needed by the Manufacturing Industries Employers ). Jurnal Pendidikan Malaysia, 34(2), 67-79.

Rhouse, S. M., \& Razak, A. A. (2006). Persepsi Ahli Akademik dan Majikan tentang Kemahiran yang Perlu Dimiliki oleh Siswazah Pengurusan Perniagaan dalam Menepati Kehendak Pasaran. Menanggapi Keberkesanan Dan Perubahan, 142-151.

Sağlam, Ş., \& Oral, B. (2010). Transformation of technical education faculties in Turkey in the process of European Union: Faculty of applied sciences. Procedia - Social and Behavioral Sciences, 2(2), 4513-4517. https://doi.org/10.1016/j.sbspro.2010.03.722

Schultz, T. W. (1967). Human capital: policy issues and research opportunities. Economic Research: Retrospect and Prospect (Vol. I).

Schultz, T. W. (1972). Human capital: policy issues and research opportunities. Economic Research: Retrospect and Prospect (Vol. I).

Unit Perancang Ekonomi. (2015). Rancangan Malaysia ke-11 (2016-2020). Unit Perancang Ekonomi, Jabatan Perdana Menteri. 